Esther D. Reed

\title{
Ecclesial Life and Political Practice: Re-Appropriating Augustine's Political Rhetoric in Contexts of Risk and Counter-Terrorism Strategy
}

\section{Context}

On 7 September 2015, Prime Minister David Cameron announced in the House of Commons that two ISIL fighters of British nationality, Reyaad Khan and Ruhul Amin, were killed in airstrikes by RAF remotely piloted aircraft. "We should be under no illusion", said the Prime Minister "their intention was the murder of British citizens, so on this occasion we ourselves took action" (Parliament. House of Commons 2015, Column 25). The Prime Minister was clear that Britain's approach to ISIL-related terrorism includes acting overseas to tackle the threat at source:

\footnotetext{
We took this action because there was no alternative. In this area, there is no Government we can work with; we have no military on the ground to detain those preparing plots; and there was nothing to suggest that Reyaad Khan would ever leave Syria or desist from his desire to murder us at home, so we had no way of preventing his planned attacks on our country without taking direct action. The US Administration have also confirmed that Junaid Hussain was killed in an American airstrike on 24 August in Raqqa (Parliament. House of Commons 2015, Columns 25-26).
}

He affirmed that the strike was not part of coalition military action against ISIL in Syria but was, rather, a targeted strike to deal with a clear, credible and specific terrorist threat to the UK at home: "There was a terrorist directing murder on our streets and no other means to stop him" (Parliament. House of Commons 2015, Column 27). The Prime Minister justified the killing of a British citizen in the sovereign territory of another nation on the grounds of a specific threat to UK security; the strike was: "necessary and proportionate for the individual self-defence of the United Kingdom”. The United Nations Security Council was to be informed of this conduct in self-defence.

Two years prior to this announcement, on 18 September 2013, Ben Emmerson, United Nations Special Rapporteur on the promotion and protection of human rights and fundamental freedoms expressed concern in an interim report about a number of legal questions on which there was no clear international

๑ OpenAccess. (C) 2019 Esther D. Reed, publiziert von De Gruyter. (cc) BY-Nc-SA Dieses Werk ist lizenziert unter der Creative Commons Attribution-NonCommercial-ShareAlike 4.0 Lizenz. 
consensus around consent by a state to the use of force by another state on its territory, when a state is unable or unwilling to take action against armed groups within its borders. At issue, said Emmerson, was the scope of anticipatory selfdefence, how the test of whether a deprivation of life is arbitrary is to be applied, and, yet more significantly, whether the threshold rules for engaging international humanitarian law remain primarily territorial in character or are to be determined by levels of violence on a case-by-case basis (Emmerson 2013, paras. 51-68). Emmerson recognised that questions remained for many concerning the right to self-defence and the geographical location of lethal targeting. While acknowledging that there was no clear international consensus, however, he has called for efforts to seek agreement between states on these issues, and urged the United States in particular to clarify its position.

Also in September 2013, Christof Heyns, in his report as a United Nations Special Rapporteur on extrajudicial, summary or arbitrary executions, urged that global security required states to follow existing international law when using drones for targeted killing:

Peace should be the norm, yet such scenarios risk making its derogation the rule by privileging force over long-term peaceful alternatives. The expansive use of armed drones by the first States to acquire them, if not challenged, can do structural damage to the cornerstones of international security and set precedents that undermine the protection of life across the globe in the longer term (Heyns 2013a, para. 16).

Heyns called for transparency by states using armed drones, disclosure of criteria for targeting, and the bringing of practices and policies in line with international standards, "including their standing orders and rules of engagement as well as their targeting norms" (Heyns 2013a, para. 109). More generally, he was concerned with the lowering of standards for the use of lethal force:

I am in particular concerned about the emergence of an approach in terms of which selfdefence, especially interpreted in this way, would be seen as a stand-alone or independent defence of the deadly use of drones or targeted killing, in general. In terms of such an approach, the risk is that neither IHRL nor IHL norms are applied as a secondary regime, to govern the use of force against individuals. The effect of an approach that self-defence is an independent and sole justification for targeted killing would risk expanding, for all States, the notion of who can be targeted and killed, as well as the notion of where such killings may take place (Heyns 2013b, p. 4).

Heyns was concerned inter alia that drone technology made the political decision to kill terror suspects so much easier; this technology gives nation states the capacity to deploy deadly and targeted force on the territories of other states without immediate threat to military service personnel. 
In the UK, a Joint Committee on Human Rights inquiry into the UK Government's policy on the use of drones for targeted killing was announced on 29 October 2015. Chaired by Rt Hon Harriet Harman MP, this inquiry sought clarification of Government policy, its legal basis, decision-making procedures that should precede such a legal use of force, and mechanisms for accountability. Its conclusions included the recommendation that the Government provides clarification of its position on the following legal questions:

- its understanding of the meaning of the requirements of "armed attack" and "imminence" in the international law of self-defence;

- the grounds on which the Government considers the Law of War to apply to a use of lethal force outside armed conflict;

- its view as to whether Article 2 ECHR applies to a use of lethal force outside armed conflict, and if not why not;

- $\quad$ its understanding of the meaning of the requirements in Article 2 ECHR that the use of force be no more than absolutely necessary, and that there is a real and immediate threat of unlawful violence, in the context of the threat posed by ISIL/Da'esh; and

- $\quad$ its understanding of the legal basis on which the UK takes part in or contributes to the use of lethal force outside armed conflict by the US or any other country adopting the same or a similar view with regard to the use of lethal force (Parliament. House of Lords and House of Commons Joint Committee on Human Rights 2016, pp. 84-85).

The counter-move to the position implied in these questions is, of course, is that security threats are changing. For present purposes we note a similar concern about the lawfulness and ethics of the inquiry's conclusions voiced by international lawyer Mary Ellen O’Connell. She argued that the United Kingdom Parliamentary Joint Committee on Human Rights began its report on UK targeted killing in the wrong place; it began with drone technology, moved on to terrorism, and only then reached the appropriate starting point: the right to life (O'Connell 2016, p. 205). Similarly, investigative journalist Chris Cole has challenged the adequacy of Government responses to the Joint Committee on Human Rights inquiry's requests for clarifications. So, for instance, he challenges the vagueness with which the Ministry of Defence 2017 Joint Doctrine Publication 0 - 30.2 Unmanned Aircraft Systems treats these issues. "The document seems to be attempting to 'define away' issues relating to the development of autonomous weapons", he says "and aiming to providing reassurance rather than substance" (Cole 2017, para. 3). Legal and ethical challenges include the meaning of 'imminence' in the international law of self-defence and, more generally, the need for a strong legal framework. Threats from terrorist attacks are real. Different kinds of expo- 
sure to danger are associated with the degradation of international law and the consequences of taking Action regarding a purported risk that might not be realised; issues concerning international justice, institutional responsibility and moral hazard run alongside issues of national defence.

\section{Attitudes to Risk}

The backdrop to the claim advanced in this essay that Augustine's discussion of (in)ordinate loves still has relevance in the liberal, democratic West, where the threat of terrorism is a factor in our national life, is coloured by societal attitudes to risk. Of interest is whether and/or how attitudes to risk might bear upon attitudes to international justice in the face of cross-border terrorist activity and shifts toward the reconfiguring of war as risk management (Heng 2009, p. 1). ${ }^{1}$ More specifically, the issue is how the language of risk and a developing conceptuality associated with risk calculation is expanding into discussions previously characterised in terms of threats and dangers, and what implications might follow for protections against the degradation of the international legal order (Bowring 2008, pp. 39-60), with the claim being that Augustine's political rhetoric puts questions to any present-day reduction of wide and complex securityrelated issues to the minimalist ethos of the risk society (Heng 2009, pp. 34-35, 144-146).

Since Mary Douglas and Aaron Wildavsky worked on risk, culture and perceptions of uncertainty in the 1980s, a central assumption in sociology and political theory has been that risk is a social construction in particular historical and cultural contexts (Douglas/Wildavsky 1982, passim). Ulrich Beck brought the concepts of risk and risk research to prominence in sociology and social theory over the past few decades, and is widely recognised has having expressed concerns about the consequences of modernity, fears about risk and security as a result of globalisation and its implications for the state and social organisation (Beck 1999). Beck's expansion of the concept of risk to include everything from localised hazards to the looming catastrophe of climate change could tend us toward conceptual and emotional muddle. For Beck, the idea of "the risk society" is shorthand for his account of the transition from "modern" industrial societies wherein, broadly speaking, risk was conceived as calculable to "postmodern" societies trust in the calculability of risk is waning, new paradigms of uncertainty become entrenched, and a sense of global risk opens up complex moral and po-

1 I am grateful to James Page for conversation on this point. 
litical spaces of responsibility individuals must negotiate for themselves. Risk as we are experiencing it, for Beck, is a phenomenon of a godless world wherein anxiety is becoming the dominant cultural grammar, with risks experienced at the national level inseparable from risks at the global level that are variously economic, environmental, geopolitical, societal and technological (Beck 1999, p. 333).

Risk assessment can enable immoral behaviours or be a morally responsible endeavour, albeit not context-free or politically non-committed. Those who accept with Ulrich Beck, Christopher Coker, et al., that the idea of risk is the predominant political reality of our times, rapidly find themselves in debates about how risk and responsibility are intrinsically connected. At the least, the morally responsible endeavour of risk analysis is tied closely to the ways that risk is constructed and experienced differently in different cultural contexts, influenced or determined by social factors such as group membership and media portrayals, and fear as an ever-expanding part of $21^{\text {st }}$-century life in relatively developed countries. More problematically, giving 'the risk society' paradigm prominence in consideration of national security strategies might subtly influence attitudes to peace-making, critical maintenance of the rule of law, the promotion of international stability, etc., by focussing attention instead upon risk calculation and management. Beck himself recognises that concentration on those risks that governments believe are calculable and controllable can distract from unexpected disasters barely visible on the horizon, and that we seem to be moving from a world of enemies to one of dangers and risk (Beck 1999, pp. 3, 47). Following Augustine's lead, the challenge in what follows is not to denounce concerns about risk and the associated need for security - this would be perverse - but to discern whether and/or when these (at least partially) virtuous endeavours tip into vice, notably, unlawfulness, the relaxation and expansion of long-established rules to delimit the use of armed force, inattention to the due process of law, the prospect of perpetual war, and sometimes a mask for murder.

Questions about risk are not new. The mythic figure of Icarus avoided the risks of flying too low, where mists and rain might have weighed him down, but was drawn toward the sun's brilliant heat that melted the wax and he fell into the Aegean sea. What has changed is how risk is being assessed politically, how awareness of risk is becoming a force for change, how the rhetoric of risk management plays with electorates, and how perennial uncertainty is a driver for both action and inaction in defence, security, and other features of international relations. Christopher Coker has commented most directly on how national security strategies have moved in recent years from preoccupation with deterrence, defence and imminent dangers, to the language and practices of risk, awareness, pre-emption, precaution, surveillance, and vulnerability. His obser- 
vations on the effects of anxiety before an unknown and uncertain future stand out. As governments lack confidence that we can manage risk and strategise insecurity, Coker underscores the role of anxiety as the dominant logic of the risk society. "What is specific to many of our own anxieties", he argues "is that they exist in the absence of any looming historical disaster" (Coker 2009, p. 73). Donald Rumsfeld's phrase "unknown unknowns" is symptomatic of an important change rather than simply a tautological coinage and expresses high levels of anxiety in the face of uncertainty, unknown risks and the almost ungraspable complexity of the risks that we can begin to anticipate (Coker 2009, p. ix). Aware of such levels of anxiety, Coker anticipates an increasing petrification of political processes and overly quick justification of violent responses to an increasingly wide range of risks: "We are now in the business of 'managing insecurity' or 'enabling greater or lesser stability' or guaranteeing better 'service provision”” (Coker 2009, p. 17).

In what follows, the proposed re-appropriation of Augustine's political rhetoric leans us toward not getting overly preoccupied with risk, that is, with calculating the probability that unwanted events might occur but, instead, toward examining our attitudes to risk such that discourse about the (dis)ordering of loves might yet yield "rhetorical tools and knives" (Badiou 2006, p. 34) that expose "the repetition of disasters" in present-day liberal democratic responses to global terrorism as much as in ancient Rome.

\section{Politics East of Eden}

Most readings of Augustine's politics emphasise the presence of sin in human affairs (Niebuhr 1995, p. 120). Augustine is often held to have a low view of the ends of politics and purposes of human law after the fall. His so-called realism or highlighting of the "sense of the tragic" with respect to human nature is typically seen as "eschewing the kind of utopian ideologies that were so destructive in the twentieth century" (Smith 2005, p. 188). As Eric Gregory puts it: "Political Augustinians are rarely accused of sentimentalist naïveté” (Gregory 2008, p. 35). Augustine is often held to have had such a low view of human law and politics after the fall that his theology of law is preoccupied with restraining disorder and lawlessness not the directing of societies toward peaceable living. Human justice rarely, if ever, gets beyond the returning of evil for evil; imperial justice is not about forgiveness but punishment.

This is not the end of the story, however. That Augustine laments and lambasts the political life of Rome presupposes the proper purpose(s) of politics within divine providence; politics is "the field on which various types of 
human excellence are necessarily cultivated" (von Heyking 2001, pp. 51- 52). Despite the ravaging effects of sin, there is a sense in which, for Augustine, the natural and educative purpose of politics remains. In Eden, says Augustine, politics is the proper activity of rational beings seeking after their perfection: human beings are educated and learn; crops and animals are cared for and cultivated; societies are governed and diverse arts are practised (Augustine no date given, Liber 8, Cap. 9, Sect. 17). The essence of politics proper is the bond of concord that unites Edenic human being as social:

God therefore created only one single man: not, certainly, that he might be alone and bereft of human society, but that, by this means, the unity of society and the bond of concord might be commended to him more forcefully (Augustine 1998, Bk XII, Ch. 22, p. 533).

Divine providence has provided for the government of the universe, including the physical motion of the planets, beauty of the seasons, and capacity of fire both to heat for cooking and consume destructively:

All natures, then, simply because they exist and therefore have a species of their own, a kind of their own, and a certain peace of their own, are certainly good. ... they tend in the scheme of divine providence to that end which is embraced in the principle of the government of the universe (Augustine 1998, Bk XII, Ch. 5, p. 504).

Moreover, natural providence provides not only that humans live within the affection of kinship but also socially and politically. Voluntary providence, that is, which operates in the activities of humans (and angels) such that they may administer societies, practice the arts of healing, technology, education, and such like, under God. East of Eden, in the domain of voluntary providence, the purpose of politics remains essentially the same - namely, the actualising of our natural sociality in the multiplicity of roles required for co-existence in an ordered concord of obedience to divine ordinances. As von Heyking summarises: "After the Fall, politics is characterized by coercion to restrain inordinate wills, by the essential collective action problem of organization and education remains" (von Heyking 2001, p 66). Human politics cannot attain its perfections. Even Solomon with all his wisdom did not attain these heights: "if anyone hopes for so great a good as this in this world, and on this earth, his wisdom is but folly" (Augustine 1998, Bk XVII, Ch. 13, p. 801). The bond of concord, which is an end of politics, requires continual mindfulness of the kind of wholeness of sociality for which humankind has been created, and is damaged by sins of concupiscence or other harms arising from evil or destructive desires (Augustine 1998, Bk IV, Ch. 3, p. 147). 
The contradiction of earthly government lies in its being both instituted by God for some kind of ordering toward common good and imbued with violence from its very birth. Augustine's mournful telling of the history of Rome implies frequently that law's violence is preferable to disorder and as a way of countering the manifestations of fallen human nature. Secular law must constitute the conditions for peaceable and ordered co-existence, orienting all things toward "an ordered concord of civic obedience and rule in order to secure a kind of co-operation of men's wills for the sake of attaining the things which belong to this mortal life" (Augustine 1998, Bk XIX, Ch. 17, p. 945). Ensuring that law achieves this purpose requires constant vigilance because violence is at the core of earthly empire and no wishful thinking can erase this. Hence Augustine's justification even of servitude as a punishment for the violation of the order of peace that humankind seeks by nature (Augustine 1998, Bk XIX, Ch. 15, p. 943). Hence the deplorability and yet seeming necessity of waging just wars (L. iusta bella): "For it is the iniquity of the opposing side that imposes upon the wise man the duty of waging wars” (Augustine 1998, Bk XIX, Ch. 7, p. 929). Augustine calls all to reflect upon this misery. If anyone does this without anguish of soul, he says, their condition is still more miserable. The bond of peace and society that is the Roman Empire and its capital city has been brought about only by outpourings of human blood. The city of this world seems only to effect peace and a semblance of justice by violent means. These realities of the fallen human condition do not excuse state violence or remove any from the obligations under God of harming no-one and doing good to all, so far as they can (Augustine 1998, Bk XIX, Ch. 14, p. 941). The precepts of the Mosaic law, including the prohibition against murder given to the Hebrew people, are now spread abroad among all the nations such that none is without some knowledge of the laws of God (Augustine 1998, Bk XIX, Ch. 23, pp. 958-959). The peace enjoyed by all estranged from God is not to be despised because a form of peace, but wretched nonetheless (Augustine 1998, Bk XIX, Ch. 26, pp. 961-962).

Augustine was not starry-eyed in his dealings with the law of empire. All the activities of civic life are enveloped in shadow or darkness in his tenebris vitae socialis (Augustine 1998, Bk XIX, Ch. 6, p. 927), rather than in the light of divine truth (Rist 1994, p. 215). The City of God especially indicates the grave dilemmas faced by lawgivers and magistrates who want to order human affairs will. The good man must often act in ways that he would long to avoid, for the world of second or fallen nature is set over against the heavenly city where fallen nature is restored by grace to purity and made perfect in Christ to enjoy eternal happiness. As bishop, he approached civil officials to intercede on behalf of debtors, got involved in day-to-day legal conflicts, commented on the duties of judges and how well they performed their role, intervened according to the cus- 
tom of the day to ask judges to mitigate the sentence and to punish more leniently than the laws commanded, offered suggestions about how mediation might take place between disputing claimants, as well as helping Christians settle disputes amongst themselves about the sale of goods, disputes over land, standards of evidence, and more (Kuhn 2007, pp. 81-82; Augustine 1961, Bk VI, Chs. 8, 13; Augustine 1887, Letter 139.2). In other words, there is ample evidence of Augustine's knowledge of the civil laws of his day, his proactive engagement with legal processes, and at least one example of his chastising churches for falling below the standards of imperial jurisprudence in their own affairs. Pilgrims journeying toward the heavenly city need the peace and security of secular order and so must obey the laws of the earthly city whereby the things necessary for the support of this mortal life are administered. He was clear that all the activities of civic life are enveloped in shadow or darkness in the light of Civitas Dei (Rist 1996, p. 215). Nevertheless, laws properly enacted are for the protection of societies not the furtherance of political influence. Even east of Eden, the purpose of law is to establish and maintain "the tranquility of order" (Augustine 1998, Bk XIX, Ch. 13, p. 938).

\section{Rhetorical "Tools and Knives"}

While attention has been paid to the rhetorical aspects of Confessions, the sermons and On Christian Doctrine, relatively few scholars have examined the political rhetoric in the City of God. John von Heyking's Augustine and Politics as Longing in the World is a noted exception that examines how Augustine heaps scorn on the pretensions of Rome's leaders whilst analysing simultaneously how the quest for glory that dominated Roman life decomposes into inordinate passions and warning believers against supposing that Christianity "has solved the problem of reconciling wisdom and power" (von Heyking 2001, p. 18). So, for instance, von Heyking draws attention to how some of Augustine's most extreme claims about the moral destitution of the Romans are made in relation to the glory they loved ardently:

They chose to live for it, and they did not hesitate to die for it ... It was, therefore, this avidity for praise and passion for glory that accomplished so many wonderous things; things which were doubtless praiseworthy and glorious in the estimation of men (Augustine 1998, Bk V, Ch. 12, p. 207).

Beyond straightforward denunciation of Roman practices and ironic praise of Rome's values, Augustine probes how the lust for glory is in danger of degener- 
ating into vexing "the sea and the lands and the sky with her terror" (Augustine 1998, Bk V, Ch. 12, p. 208), bringing servitude to others, modes of civil religion that are impious, failure to restrain baser lusts (Augustine 1998, Bk V, Ch. 14, p. 213), the vices of cruelty and luxury (Augustine 1998, Bk V, Ch. 19, p. 224), and the extension of wars beyond their course, one of his points being that the Roman passion for glory was not virtuous but rooted in fear and characterised by loss of self-restraint such that its practices that must be condemned as "vile" (Weithman 2014, p. 243). Inordinate love of glory degenerates rapidly into the lust for domination (von Heyking 2001, p. 50). Transient glory won politically or in battle can produce a restless lust for mastery that distracts from proper creaturely glorying in God and can disintegrate into contempt for God and harm to oneself and others (Augustine 1998, Bk XIV, Ch. 28, pp. 632-633; Bk XV, Ch. 4, pp. 638-639). Augustine excoriates Rome for loving virtues for ends other than their peace and unity: “[B]ecause they did not love glory for the sake of justice, but seem rather to have loved justice for the sake of glory, they subsequently broke the treaty of peace which they had made" (Augustine 1998, Bk V, Ch. 22, p. 229).

The Roman quest for glory was not always reprehensible. Augustine cites Sallust in suggesting that glory can be won either by virtue or vice (Augustine 1998, Bk V, Ch. 12, p. 208). Some virtues contributed to raising the empire and public service, and, functioned sometimes to repress even less worthy desires. Glory-hungry ancient Romans did not hesitate to die for the republic and contributed to a working schema of government. "It was, therefore, this avidity for praise and passion for glory that accomplished so many wonderous things: things which were doubtless praiseworthy and glorious in the estimation of men" (Augustine 1998, Bk V, Ch. 12, p. 208). For Augustine, the love of glory, which is of itself a vice, may be reckoned virtuous when by it a greater vice is restrained. He remains critical, however, of philosophers who subordinate virtues to limited or inordinate ends:

[T]hey depict Pleasure as some voluptuous queen seated upon a royal throne. The virtues serve her as handmaidens, watching for her nod so that they may do whatever she commands. She commands Prudence vigilantly to enquire how Pleasure may reign and be safe. She commands Justice to bestow whatever benefits she can, in order to secure the friendships necessary for bodily comfort ... She commands Temperance to take only a certain quantity of food, no matter how delicious, lest a harmful lack of moderation should interfere with health and therefore ... with Pleasure (Augustine 1998, Bk V, Ch. 20, p. 226).

The virtues become the slaves of imperious and disreputable Pleasure. Glory is puffed up and served falsely by the virtues: "for Prudence to foresee nothing, Justice to bestow nothing, Fortitude to endure nothing, and Temperance to mod- 
erate nothing other than for the sake of pleasing men and serving an inflated glory" (Augustine 1998, Bk V, Ch. 20, p. 227).

Now the prominence of this desire in the character of the Romans is shown by the fact that the temples of the gods which they established in the closest proximity to one another were those of Virtue and Honour (for they took the gifts of God to be gods themselves) (Augustine 1998, Bk V, Ch. 12, p. 210).

Today, we do not build temples to virtue and honour but elevate certain concepts and/or principles, such as collective security and democracy, to the status of quasi-religious symbols, the observance of which can substitute for government for the international common good. As the miser forsakes justice out of his love for gold, the fault lies not with the gold but with the person if love of the gold is not properly subordinated to love of other goods (Augustine 1998, Bk XV, Ch. 22, p. 679).

\section{5 (In)Ordinate Love of Security}

Maintaining the safety of the city is an ordinate love, albeit not ultimate. Augustine did not dispute the duty of a ruler to maintain the safety of a city in the temporal order. Nor, says Heyking, did Augustine reject Cicero's analogy between the city and the eternity of the world even though he modified Cicero's view that the world is eternal (von Heyking 2001, p. 58). While making clear Cicero's false belief regarding the eternity of Rome, Augustine allowed the analogy to pass because of the proper responsibilities upon Rome's leaders "to establish and maintain a city as a little world within God's creation”. That the city appears eternal from the human perspective is false but does not render useless the work of governance pursued by those in error. At issue is when the proper concern for security and the protection of citizens tips into vice.

Substituting "security" for Augustine's discussions of "pleasure" and "glory", our concern becomes whether and/or when our elected governments did not love security for the sake of justice or the commonweal but seem rather to have loved each for the sake of security, thereby undermining the values worthy of empire. As for Augustine, a task for the church, and the disciplines of Christian ethics and political theology, is to hold up a mirror to those wielding political and military might to see where (at least partially) virtuous intent falls into excess, aggression, illegality and yet more war. Time and again, Augustine probes where and how (at least partially) virtuous intent falls into excess, aggression, illegality and yet more war, and/or when it results in governance 
for those governed, taking counsel (L. consulere) with the elders, and seeking after just peace. At issue for our purposes similarly is when the quest for something not entirely without virtue (not glory but security) degenerates, or becomes vulnerable to degeneration into illegality, violence, the lust for domination, and other vices.

Augustine's warning is not to elevate too high any principle or precept, virtue or political objective. The Romans built temples to virtue and honour, worshipping as gods the gifts of God, and sought the high judgement of fellow citizens before the true God. Despite their inherent worth, temples to virtue and honour produced the usual corrupt politics not government for the commonweal:

And what is meant by "good arts" here, clearly, is the use of virtuous means rather than deceitful intrigue to arrive at honour, glory and power. Good and base men alike desire these things; but the former - the good man, that is - strives after them by the true way. This way is virtue ....

Now the prominence of this desire in the character of the Romans is shown by the fact that the temples of the gods which they established in the closest proximity to one another were those of Virtue and Honour (for they took the gifts of God to be gods themselves) (Augustine 1998, Bk V, Ch. 12, p. 210).

Augustine accepts that virtue and honour, as recognised by Rome, are goods and, indeed, the gifts of God. But the Romans made these goods into gods such that worship of virtue and honour came to detract from attention to the higher goods and worship of the true God. When revered for their own sake, virtue and honour tend their worshippers toward corruption, luxury and idleness, and away from attention to public good: "after the city had become corrupted by luxury and idleness" many more vices beset private citizens alongside generals and magistrates (Augustine 1998, Bk V, Ch. 12, p. 212). Virtue, honour and security can all be ordinate and also inordinate objects of love.

Note further his related warning against making "foreign iniquity" and excuse for military action desired for other political purposes. "Foreign iniquity" is sometimes welcomed, writes Augustine, because it serves political agendas:

He prays ill, therefore, who desires to have someone to hate or to fear in order to have someone to conquer. If, then, it was by waging wars that were just, and not impious or unrighteous, that the Romans were able to acquire so great an empire, should they not worship even Foreign Iniquity as a goddess? For we see that Foreign Iniquity has contributed much to the increase in the breadth of the empire, by making foreigners so unjust that they become peoples against whom just wars may be waged and the empire thereby enlarged (Augustine 1998, Bk IV, Ch. 15, p. 162). 
At the least, Augustine requires his readers today to exercise an ethic of suspicion in this regard.

Whether Augustine went too far in capitulating to the demands of the Roman Empire for security and expansion remains an open question. He condemned the gratuitous violence and cruelty of prominent generals but seemed to take for granted sometimes that the leaders of the empire would seek to extend territory and the pax Romana, with all the violence that entailed. He comments wearily but with a degree of resignation on the constant and unremitting warfare by which Rome grew to gigantic size: "Why must an empire be unquiet in order to be great?" "Consider the human body", he writes, "[i]s it not enough to have moderate stature and good health?” (Augustine 1998, Bk III, Ch. 10, p. 103). An oversized body experiences ills that are greater in proportion to the size of its members. Augustine is troubled by the fury of war and the love of gain that drove Rome's expansion but he accepts that many campaigns began as counter-offensives and the need to repel the savage incursions of enemies. Citing Sallust's lauding of Rome's armed defence of its liberty, fatherland and families, and the practice of conferring benefits upon subjugates peoples, Augustine appears to deem such international relations tolerable: "When Rome increased by these means, she did so honourably" (Augustine 1998, Bk III, Ch. 10, p. 104). While finding fault with individual military leaders who violated accepted norms of warfare, he broadly accepts the need to secure border territories against invaders. Nor can I tolerate Augustine's acceptance of the torturing of the Donatists. Having initially opposed the coercion of heretics, he changed his mind not for the sake of imposing orthodoxy but because of the extent and severity of Donatist violence, and because many who had been coerced with violence were grateful for the awakening:

How many of them, now rejoicing with us, speak bitterly of the weight with which their ruinous course formerly oppressed them, and confess that it was our duty to inflict annoyance upon them, in order to prevent them from perishing under the disease of lethargic habit, as under a fatal sleep! (Augustine 1887, Letter 93.1.2)

While consistently rejecting the death penalty, pleading frequently for clemency and interrogation that stopped short of torture, never concluding that heretics should be deprived of their political rights, Augustine accepted coercion with reference to Jesus' teaching in Luke 14:23: “compel them to enter" (Quoscomque inveneritis cogite intrare) (Augustine 1887, Letter 93.2.5). Whether or not we approve his decision - and I do not - Augustine lived the tension between recognition of the darkest possibilities of human sinfulness, where violent coercion is necessary for the restraint of wrongdoing and the functioning of divine providence 
through human law-making and political activity, while condemning consistently the animus dominandi.

Beware, says Augustine, the violence that engenders violence, and those wars that spawn wars:

For though there has been, and is now, no lack of enemies among foreign nations, against whom wars have always been waged, and still are being waged, yet the very breadth of the Empire has produced wars of a worse kind: that is, social and civil wars. By these, the human race is made even more miserable, either by warfare itself, waged for the sake of eventual peace, or by the constant fear that conflict will begin again (Augustine 1998, Bk XIX, Ch. 7, p. 929).

All who regard themselves as having a duty to conduct wars should reflect with pain upon such misery. Beware wars conducted without the desired end of peace! (Augustine 1998, Bk XIX, Ch. 12, p. 934) Consider also the kind of peace wished for. Even robbers and conspirators consider the kind of peace they need to prosper their ways. Cacus, the fabled Greek wild man desired to be at peace with his body: "for all his monstrous and wild savagery, his aim was peace; for he sought by these monstrous and fierce means, only to preserve the peace of his own life" (Augustine 1998, Bk XIX, Ch. 12, p. 935). How much more is the rational person drawn by the laws of their nature desirous of peace with their fellows, so far as it lies within their power. Like a body hanging upside-down and thus out of sorts, unable to breathe easily and feeling disagreeable, so individuals, communities and peoples are oriented by nature toward peace: "The peace of all things lies in the tranquility of order, and order is the disposition of equal and unequal things in such a way as to give each its proper place" (Augustine 1998, Bk XIX, Ch. 13, p. 938).

Beware the animus dominandi whereby the concern for justice gives way to a lust for mastery. The animus dominandi takes different forms and is especially abhorrent in the terrorist. But not only bandits are answerable to the demands of justice. While Augustine does not posit in City of God that justice is removed entirely from the Roman Empire, readers will be familiar with the passage in which he asserts that,"justice removed, then, (Remota itaque iustita) what are kingdoms (regna) but great bands of robbers? (latrocinia)" (Augustine 1998, Bk IV, Ch. 4, p. 147). In a now famous passage, he reduces the pretensions of empire without justice to the schemes of a petty pirate by calling both of their enterprises robberies.

For what are robberies themselves, but little kingdoms? The band itself is made up of men; it is ruled by the authority of a prince, it is knit together by the pact of the confederacy; the booty is divided by the law agreed on. If, by the admittance of abandoned men, this evil 
increases to such a degree that it holds places, fixes abodes, takes possession of cities, and subdues peoples, it assumes the more plainly the name of a kingdom, because the reality is now manifestly conferred on it, not by the removal of covetousness, but by the addition of impunity (Augustine 1998, Bk IV, Ch. 6, p. 148).

Citing Sallust, a great proponent of the virtue of Rome, Augustine observes degeneracy after the destruction of Carthage - with vices of discord, avarice and ambition. The faults that he condemns are mostly the failures of individuals within a worldview rooted in sin but Augustine condemns war for any purpose other than that of peaceable order, and the conduct of war without humaneness. Thus he inveighs against the overthrowing of the city of Syracuse without the clemency that Marcus Marcellus was reputed to have desired, and against the cruelties that occurred during the sack of Rome (Augustine 1998, Bk I, Ch. 6, pp. $10-11)$. Augustine tolerates punitive and retributive military action against invaders and the gratuitously violent, but condemns the impiety of wars waged from lust for mastery or other gain. "What a great evil it was, when the Albans were provoked into war ... How great was the impoverishment of both cities" (Augustine 1998, Bk III, Ch. 14, p. 109). The impoverishment of the Albans was physical and political but that of the Romans moral and spiritual: "Take off the cloak of vain opinion, and let such evil deeds be examined naked. ... Let the cause against Alba be stated, just as that of adultery was stated against Troy" (Augustine 1998, Bk III, Ch. 14, p. 111). The cause of war against Alba had no basis in justice but is compared by Augustine to gladiators fighting for the reward of praise. "Did it make a difference that there was no arena, and that the broader battlefields were filled with the bodies, not of two gladiators, but of multitudes belonging to two peoples?” (Augustine 1998, Bk III, Ch. 14, p. 112)

\section{Re-Appropriation}

Bringing Augustinian rhetorical analysis to bear upon highly contested debates about the ethics of domestic security and the laws of war requires that the Christian ethicist work with criteria concerning corruption and disordered loves including the animus dominandi, disorder and lawlessness. The challenge is not to denounce concerns for national security from terrorist and other attacks but to discern whether and/or when this (at least partially) virtuous objective becomes so problematic that it threatens conditions required for the realisation of peace. Augustine-influenced questions will look something like:

- Is an increasing emphasis on risk and the discourse associated with the socalled "risk society" contributing to neglect of international legal order? 
- Has countering "foreign iniquity" become an excuse for political objectives unrelated to long-term peace and international stability, the nurturing of just trading relations, conflict prevention, and so on?

- When is military action characterised by the political animus dominandi, disorder and lawlessness, and when properly constrained by a legal regime oriented toward long-term peace and stability?

- What is required to facilitate politics as the proper activity of rational beings seeking after their common perfection?

Consider the similarities between these Augustinian-influenced questions and the issues outlined.

Today, "justice being taken away" cannot simply be taken to refer to piracy, terrorism and dictatorships but also disregard of the U.N. Charter, circumvention of U.N. procedures, and failure to care adequately for the development of international law. My point is not to elevate existing international law to a quasi-mystical status that should not be touched but draw attention again to questions about whether and/or how established norms and procedures that have served to restrain the use of force, thereby reducing the incidence of armed conflicts between states, are being bypassed for less virtuous (albeit sometimes worthy) aims. Modern international law developed largely in response to Americo-European issues as a means to protect financial interests and is thus inherently problematic. This reality cannot and should not be shirked from. Nor should international law be loved for its own sake - not least because, as Simon Critchley observes, "[i]nternational law is a very nice thing, but if it fails to have an anchor in everyday social practices then it leads to a politics of abstraction" (Critchley 2007, p. 144). However, and here is a critical point, international law functions, for better or for worse, as a significant means of restraining the use of force and reducing the incidence of armed conflicts between states (although not necessarily exclusively between states) and should not be abandoned to meet the new challenges posed by terrorism. For permanent members of the United Nations Security Council especially, although not exclusively, the challenge is, to borrow Jeremy Waldron's words, how to consider "the rule of international law" in terms of the nation-state (and especially nation states as powerful as the USA) as not just a subject of international law but "additionally both a source and an official of international law” (Waldron 2010, p. 327).

Allowing international law to play "catch up" with US and UK routinised practices falls a long way short of Augustinian standards for politics east-ofEden wherein the purpose of law is for the maintenance of order and hope of peace. Augustine's warning is that purpose of law is not advancing of the inter- 
ests of global military powers per se but a just peace, understood always with reference to good greater than that of the agent with most fire-power.

\section{Bibliography}

Augustine (1887): Letters. J.G. Cunningham (Transl.). In: Nicene and Post-Nicene Fathers, First Series, Vol. 1. Philip Schaff (Ed.). Buffalo, NY: Christian Literature Publishing Co. Revised and edited for New Advent by Kevin Knight. http://www.newadvent.org/fathers/1102139. htm, visited on 5 December 2018.

Augustine (1998): Augustine: The City of God Against the Pagans. R.W. Dyson (Transl. and ed.). Cambridge: Cambridge University Press.

Augustine (1961): Confessions. R.S. Pine-Coffin (Transl. and ed.). London: Penguin.

Augustine (no date given): "De Genesi ad Litteram libri duodecim". In: S. Aurelii Augustini Opera Omnia: Patrologiae Latinae Elenchus, Vol. 34. https://www.augustinus.it/latino/ genesi_lettera/index2.htm, visited on 5 December 2018.

Badiou, Alain (2006): Polemics. Steve Corcoran (Transl.). London: Verso.

Beck, Ulrich (1999): World Risk Society. Cambridge: Polity Press.

Bowring, Bill (2008): The Degradation of the International Legal Order. Abingdon: Routledge-Cavendish.

Critchley, Simon (2007): Infinitely Demanding: Ethics of Commitment, Politics of Resistance. London: Verso.

Emmerson, Ben (2013): "Report of the Special Rapporteur on the Promotion and Protection of Human Rights and Fundamental Freedoms while Countering Terrorism". United Nations General Assembly A/HRC/34/61, 18 September 2013. https://undocs.org/A/HRC/34/61, visited on 5 December 2018.

Coker, Christopher (2009): War in an Age of Risk. Cambridge: Polity Press.

Cole, Chris (2017): “New MoD Document on Use of Drones, Same Old Spin”. In: Drone Wars UK, 13 September 2017. https://dronewars.net/2017/09/13/new-mod-document-on-useof-drones-same-old-spin/, visited on 5 December 2018.

Douglas, Mary/Wildavsky, Aaron (1982): Risk and Culture: An Essay on the Selection of Technical and Environmental Dangers. Oakland: University of California Press.

Gregory, Eric (2008): Politics and the Order of Love: An Augustinian Ethic of Political Citizenship. Chicago: University of Chicago Press.

Joint Select Committee (2015): "UK Policy on Use of Drones for Targeted Killing Inquiry". http://www.parliament.uk/business/committees/committees-a-z/joint-select/humanrights-committee/news-parliament-2015/uk-drone-policy-evidence-15-16/. Citations are taken from the Second Report of Session 2015-16 (HL Paper 141, HC 574), https://pub lications.parliament.uk/pa/jt201516/jtselect/jtrights/574/574.pdf, visited on 3 March 2018.

Heng, Yee-Kuang (2009): War as Risk. London: Routledge.

Heyking, John von (2001): Augustine and Politics as Longing in the World. Columbia: University of Missouri Press.

Heyns, Christof (2013a): "Report of the Special Rapporteur on Extrajudicial, Summary or Arbitrary Executions”. United Nations General Assembly A/68/382, 13 September 2013. 
http://www.justsecurity.org/wp-content/uploads/2013/10/UN-Special-Rapporteur-Extra judicial-Christof-Heyns-Report-Drones.pdf, visited on 5 December 2018.

Heyns, Christof (2013b): "Statement by Special Rapporteur on Extrajudicial, Summary or Arbitrary Executions". 68th Session of the General Assembly of the United Nations, Item 69(b), 25 October 2013. https://papersmart.unmeetings.org/media2/703363/statementby-christof-heyns-item-69b.pdf, visited on 5 December 2018.

Kuhn, Eva-Maria (2007): "Justice Applied by the Episcopal Arbitrator: Augustine and the Implementation of Divine Justice”. In: Ethics \& Politics 9. No. 2, pp. 71-104.

Ministry of Defence (2017): “Joint Doctrine Publication 0-30.2 Unmanned Aircraft Systems". https://www.gov.uk/government/uploads/system/uploads/attachment_data/file/673940/ doctrine_uk_uas_jdp_0_30_2.pdf, visited on 5 December 2018.

Niebuhr, Reinhold (1995): “Augustine’s Political Realism”. In: Dorothy Donnelly (Ed.): The City of God: A Collection of Critical Essays. New York: Peter Land, pp. 119-134.

O'Connell, Mary Ellen (2016): “The Law on Lethal Force Begins with the Right to Life”. In: Journal on the Use of Force and International Law 3. No. 2, pp. 205-209.

Parliament. House of Commons (2015): Daily Hansard, Monday 7 September 2015. https:// publications.parliament.uk/pa/cm201516/cmhansrd/cm150907/debtext/150907-0001. $\mathrm{htm}$, visited on 5 December 2018.

Parliament. House of Lords and House of Commons Joint Committee on Human Rights (2016): “The Government's Policy on the Use of Drones for Targeted Killing”. Citations are taken from the Second Report of Session 2015-16 (HL Paper 141, HC 574), https://pub lications.parliament.uk/pa/jt201516/jtselect/jtrights/574/574.pdf, visited on 5 December 2018.

Parliament. Joint Select Committee (2015): "UK Policy on Use of Drones for Targeted Killing Inquiry”. 29 October 2015. https://www.parliament.uk/business/committees/committeesa-z/joint-select/human-rights-committee/news-parliament-2015/uk-drone-policy-evi dence-15-16/, visited on 5 December 2018.

Rist, John M. (1994): Augustine: Ancient Thought Baptized. Cambridge: Cambridge University Press.

Smith, Thomas W. (2005): “The Glory and Tragedy of Politics”. In: John Doody/Kevin L. Hughes/Kim Paffenroth (Eds): Augustine and Politics. Lanham: Lexington Books, pp. $187-213$.

Waldron, Jeremy (2010): Torture, Terror, and Trade-Offs: Philosophy for the White House. Oxford: Oxford University Press.

Weithman, Paul (2014): “Augustine’s Political Philosophy”. In: David Vincent Meconi/Eleonore Stump (Eds.): The Cambridge Companion to Augustine. 2nd ed. Cambridge: Cambridge University Press, pp. 231-250. 